\title{
PENGEMBANGAN MODEL LATIHAN KARATE KIDS PADA ANAK USIA SEKOLAH DASAR KELAS ATAS
}

\section{DEVELOPING A KARATE KIDS TRAINING MODEL FOR HIGHER PRIMARY SCHOOL AGE CHILDREN}

\author{
Widha Srianto, Sugeng Purwanto \\ SD Budi Mulia Dua Yogyakarta, Universitas Negeri Yogyakarta \\ Widha.srianto@yahoo.com, sugeng_purwanto77@yahoo.com
}

\begin{abstract}
Abstrak
Penelitian ini bertujuan untuk menghasilkan model latihan karate kids pada anak usia sekolah dasar (SD) kelas atas (10-12 tahun). Penelitian pengembangan ini dilakukan dengan mengadaptasi langkah-langkah penelitian sebagai berikut: (1) pengumpulan informasi di lapangan, (2) melakukan analisis terhadap informasi yang telah dikumpulkan, (3) mengembangkan produk awal, (4) validasi ahli dan revisi, (5) uji coba lapangan skala kecil dan revisi, (6) uji coba lapangan skala besar dan revisi, dan (7) pembuatan produk final. Uji coba skala kecil dilakukan di klub Forki Kota Yogyakarta berjumlah 7 anak. Uji coba skala besar di klub Inkanas DIY berjumlah 16 anak. Instrumen pengumpulan data yang digunakan yaitu: (1) pedoman wawancara, (2) skala nilai, (3) pedoman observasi model, (4) pedoman observasi keefektifan model, dan (5) kuesioner untuk siswa. Teknik analisis data yang dilakukan yaitu analisis deskriptif kuantitatif dan analisis deskriptif kualitatif. Hasil penelitian ini berupa model latihan karate kids pada anak usia SD kelas atas (10-12 tahun) yaitu: (1) model latihan maegeri, (2) model latihan gyaku tsuki, (3) model latihan mawashigeri, dan (4) model latihan oi tsuki. Dari hasil analisis data penilaian para ahli materi dan kuesioner anak, dapat ditarik kesimpulan bahwa model latihan karate kids pada anak usia SD kelas atas (10-12 tahun) ini dinilai baik dan efektif.
\end{abstract}

Kata kunci: model latihan, karate kids

\begin{abstract}
The development of this model is expected to become a satisfactory and effective training model. This research and development was conducted by adapting the research steps as follows: (1) the collection of information in the field, (2) the analysis of the information collected, (3) the development of the initial product, (4) expert validation and revision, (5) the small-scale field trials and revisions, (6) large-scale field trials and revisions, and (7) the establishment of the final product. The smallscale trials were applied to children joining the Yogyakarta Forki Karate Club with the total of seven children. The large-scale trials were applied to children joining the Inkanas DIY Karate Club with the total of 16 children. The data collecting instruments were: (1) interview guide, (2) a value scale, (3) observation guide of the model, (4) an observation guide of the model's effectiveness, and (5) a questionnaire for the karate students. The data analysis method utilized a quantitative descriptive analysis and a qualitative descriptive analysis. The research resulted in a karate kids training model designed for the higher primary school age children (10-12 year olds), which consists of: (1) the maegeri training model, (2) the gyaku tsuki training model, (3) the mawashigeri training model, and (4) the oi tsuki training model. Based on the data analysis derived from expert assessment and children questionnaires, it is concluded that the karate kids training model for the higher primary school age children (10-12 year olds) is considered as satisfactory and effective.
\end{abstract}

Keywords: exercise models, karate kids. 


\section{Pendahuluan}

Menurut Purwanto (2009, pp.173-174) sejarah karate pada awalnya diduga berasal dari India kemudian menjalar ke Cina, dengan tujuan Budhi Dharma dalam mengajarkan agama di Cina. Dari Cina, gama Budha masuk di Okinawa-Jepang akan tetapi pada waktu itu pulau Okinawa sudah dikuasai Jepang, dan penduduk Okinawa dilarang memiliki senjata..

Seiring dengan perkembangan zaman, kemajuan olahraga karate terlihat pada banyaknya kejuaraan yang dilaksanakan dan olahraga karate banyak dipertandingkan dengan tujuan untuk mencari bibit-bibit atlet yang potensial. Karate termasuk cabang olahraga yang dipertandingkan dalam O2SN (olimpiade olahraga siswa nasional), POPNAS dan POMNAS. Pada O2SN diselenggarakan mulai tingkat sekolah dasar (SD) hingga sekolah menengah atas (SMA). Peserta tingkat sekolah dasar adalah anak-anak yang duduk dibangku sekolah dari kelas satu sampai dengan kelas lima sekolah dasar. Anak-anak melakukan seleksi dari tingkat kecamatan hingga mewakili provinsi untuk mengikuti O2SN. Keterlibatan anak dalam berbagai kejuaran yang diadakan dari tingkat daerah sampai tingkat internasional harus disiapkan dengan program latihan dan model latihan yang sesuai untuk usia anak-anak.

Kecakapan pada masa anak-anak menjadi masa yang krusial untuk memberikan berbagai pengalaman gerak karena pertumbuhan dan perkembangan anak secara pesat terjadi pada masa ini. Pentingnya penerimaan berbagai gerakan atau teknik pada anak-anak, dapat dianalogikan jika anak yang sejak usia dini memiliki keterampilan gerakan maka akan lebih mudah menerima keterampilan gerak yang serupa di masa yang akan datang. Artinya bahwa anak-anak akan memiliki gerakan yang efisien dan terampil karena keterampilan gerak tersebut telah termemori dalam otaknya dan daya tangkap lebih cepat.

Menurut Mini (2003, p.17) anak lebih menyukai permainan dan biasanya kegiatan yang memadukan proses belajar, disiplin, dan bermain. Anak-anak sebagaimana orang dewasa bisa bertindak dan melakukan semua hal dengan sangat baik ketika merasa bahagia dan gembira. Anak-anak merasa bahagia ketika ada seseorang yang mendampinginnya dan membantunya melakukan hal-hal yang menyenangkan, serta yakin bahwa ada orang yang menghargai dan mencintainya. Mini (2003, p.17) menyatakan perkembangan bakat anak-anak akan lebih optimal bila kegiatan-kegiatan anakanak dilakukan dengan suasana fun dan rekreatif. Hindari sejauh mungkin tekanan/ paksaan maupun suasana disiplin kaku pada anak, hal ini justru memperbesar kemungkinan anak menjadi down dan tidak menyukai latihan.

Perkembangan olahraga karate begitu cepat, sudah waktunya menyadari bahwa sangat perlu untuk mendidik sebuah generasi yang inovatif. Dari hasil wawancara yang dilakukan dengan pelatih di klub Inkanas Depok Sport Centre, Inkanas Hagen, dan UKM Inkai UNY dapat disimpulkan beberapa permasalahan: (1) kurangnya variasi model latihan/monoton (maju dan mundur lima kali), (2) kurangnya pendekatan permainan dan gerak multilateral untuk anak-anak, dan (3) kurangnya referensi/buku panduan melatih anak-anak.

Aktivitas jasmani yang dilakukan anakanak pada masa sekarang sangat sedikit, hal ini disebabkan karena kamajuan jaman sehingga permainan anak-anak lebih banyak dilakukan di dalam ruangan seperti: bermain play station, bermain hand phone, dan bermain game online. Sehigga sebagai pelatih harus mengerti dan memahami kebutuhan anak-anak, agar dalam proses berlatih anak merasakan kenyamanan untuk bergerak/beraktivitas sehingga anak tidak bosan pada saat berlatih karena materi latihan yang kurang variasi.

Model latihan karate kids berisi permainan dan gerak multilateral sehingga anak akan mendapatkan kegembiraan dan aktif bergerak. Pelatih olahraga harus kreatif dalam menghasilkan model permainan untuk anakanak karena anak sebagai tonggak masa depan sebuah bangsa. Model latihan karate kids bertujuan untuk mengembangkan potensi yang ada dalam diri anak-anak sehingga model latihan dibuat sedemikian menarik atau bersifat rekreatif, sehingga tanpa disadari dalam bermain sebenarnya anak sedang berlatih sehingga anak merasa senang dan materi mudah dipahami.

Dari uraian tersebut dapat dipahami bahwa kecenderungan pemberian program latihan yang monoton, konservatif, atau tradisional sehingga perlunya model latihan untuk anak-anak dengan technical approach atau menggunakan teknik pendekatan anak agar memiliki pengalaman latihan yang menyenangkan, yang dapat membantu anak dalam proses berlatih. Model latihan ini digunakan untuk anak-anak sebagai generasi penerus bangsa untuk tongak masa depan prestasi bangsa 
Indonesia di bidang olahraga karate di masa yang akan datang.

Latihan, Bermain, dan Gerak Multilateral

Sukadiyanto (2002, p.5) menyatakan istilah latihan berasal dari kata dalam bahasa Inggris yang dapat mengandung beberapa makna seperti: practice, exercise, dan training. Dalam istilah bahasa Indonesia kata-kata tersebut semuanya memiliki arti yang sama yaitu latihan namun dalam bahasa Inggris kenyataannya setiap kata tersebut memiliki maksud yang berbeda-beda, setelah diaplikasikan di lapangan memang nampak sama kegiatannya yaitu aktifitas fisik. Menurut Suharjana (2013, p.37) latihan atau training adalah suatu program yang terdiri dari beberapa exercise untuk mengembangkan kinerja, meningkatkan kemampuan fisik dalam rangka meningkatkan penampilan atau untuk meningkatkan kebugaran jasmani dan persiapan pertandingan yang berlangsung antara 2 sampai 12 bulan.

Menurut Goldstein (2012, p.5): "play has been defined as any activity freely chosen, intrinsically motivated, and personally directed. It stands outside 'ordinary' life, and is nonserious but at the same time absorbing the player intensely". Diartikan bahwa permainan diidentifikasikan sebagai setiap kegiatan yang dipilih secara bebas, termotivasi dari dalam diri sediri, dan diarahkan secara pribadi. Aktivitas ini berada di luar kehidupan biasanya, dan bersifat tidak serius tetapi pada saat yang sama pemain menyerap secara intens. Menurut Montessori (Mini, 2003, p.48) mengartikan bahwa kegiatan bermain adalah sebagai latihan jiwa dan badan demi kehidupan anak di masa depan. Berbagai permainan yang dilakukan anak merupakan latihan berbagai tugas yang akan dihadapi di masa yang akan datang.

Menurut Lumintuarso (2013, pp.21-22) atlet multilateral adalah anak pada usia 13 tahun ke bawah, anak tersebut masih belum dipersiapkan untuk mendalami latihan cabang olahraga spesialisasi/khusus. Gerak multilateral merupakan penggabungan dari berbagai gerak dasar dan dasar gerak keterampilan olahraga.

\section{Sirkuit Game untuk Karate Kids}

Menurut Suharjana (2013, p.49) latihan sirkuit training adalah bentuk latihan aerobik yang terdiri dari pos-pos latihan, yaitu antara 816 pos latihan. Latihan dilakukan dengan cara berpindah-pindah dari pos satu ke pos dua dan seterusnya hingga selesai. Pengertian latihan sirkuit game untuk karate kids adalah bentuk latihan yang mengadaptasikan prinsip latihan dengan konsep permainan, pemberian gerak multilateral, dan teknik dengan model latihan sirkuit game menggunakan beberapa alat/sarana permainan dan terdapat 6-7 pos dilakukan secara berpindah-pindah hingga selesai. Latihan karate kids dengan model sirkuit game dapat dilatihkan pada anak usia sekolah dasar kelas atas (10-12) tahun. Dalam model latihan karate kids pada anak usia sekolah dasar kelas atas akan diberikan empat model latihan, yaitu: (1) model latihan maegeri, (2) model latihan gyaku tsuki, (3) model latihan mawashigeri, dan (4) model latihan oi tsuki.

\section{Metode Penelitian}

\section{Jenis Penelitian}

Penelitian ini merupakan penelitian pengembangan (Research and Development). Menurut Borg \& Gall (2003, p.569) penelitian $\mathrm{R} \& \mathrm{D}$ adalah model pengembangan industri di mana penemuan dari penelitiannya digunakan untuk produk-produk dan aturan baru, kemudian dilakukan uji coba lapangan secara sistematis, terevaluasi, dan terstruktur sehingga peneliti menemukan kriteria yang terspesifikasi menurut keefektifan, kualitas, atau standar yang serupa.

Waktu dan Tempat Penelitian

Uji coba skala kecil dilaksanakan pada bulan Desember 2013 di Club Forki Kota Yogyakarta dan Uji coba skala besar dilaksanakan pada bulan Januari 2014 di Club Inkanas DIY.

\section{Terget/Subjek Penelitian}

Subjek coba dalam penelitian pengembangan ini adalah anak yang memiliki kriteria anak usia sekolah dasar kelas atas (10-12 tahun). Uji coba skala kecil dilaksakan Club Forki Kota Yogyakarta berjumlah 7 anak dan uji coba skala besar dilaksanakan di Club Inkanas DIY berjumlah 16 anak.

Prosedur Penelitian dan Pengembangan

Menurut Borg and Gall (1987, p.784) Mulyatiningsih (2011, p.147) 10 tahap penelitian R\&D adalah sebagai berikut:

\section{Research and Information Collection}

Peneliti melakukan kajian awal menganalisis kebutuhan, melakukan pengumpulan informasi lebih lanjut dengan melakukan studi pendahuluan baik dengan cara studi pustaka maupun wawancara langsung dengan pelatih. 
Hal yang dilakukan dalam studi pustaka yaitu dengan mengumpulkan bahan mengenai teoriteori, data, dan hasil penelitian yang terkait dengan penelitian ini

\section{Planning}

Pada tahap ini peneliti mulai menetapkan rancangan model untuk memecahkan masalah yang telah ditemukan pada tahap awal. Hal yang direncanakan antara lain: menetapkan model latihan, merumuskan tujuan secara bertahap, mengidentifikasi kegiatan-kegiatan yang dilakukan pada setiap tahap penelitian

\section{Develop Preliminary Form of Product}

Tahap ini mulai menyusun bentuk awal model dan perangkat yang diperlukan, produk awal model berupa draf awal penerapan model latihan dan instrumen alat pengumpulan data seperti lembar observasi, pedoman wawancara yang diperlukan untuk mengumpulkan semua informasi selama penerapan model. Proses penelitian pada tahap ini dengan melakukan validasi rancangan model oleh ahli materi permainan dan karate. Proses ini dilakukan sampai produk awal mencapai batas nilai tertentu yang telah ditetapkan, yang menunjukkan bahwa produk awal tersebut valid dan layak diujicobakan

\section{Preliminary Field Testing}

Sebelum dilakukan uji coba harus melakukan tahapan validasi desain terhadap model awal latihan karate kids dan memeriksa isi instrumen secara sistematis serta mengevaluasi relevansi dengan variabel yang ditentukan. Hal ini dilakukan untuk mengetahui sejauh mana instrumen yang digunakan dalam penelitian telah mencerminkan keseluruhan aspek yang diukur

\section{Main Product Revision}

Setelah melakukan proses validasi, expert judgment menilai dan memberi masukan terhadap produk awal, proses ini dilakukan sampai menunjukkan bahwa produk awal tersebut valid dan layak diujicobakan

\section{Main Filed Testing}

Uji coba produk skala kecil dilaksanakan di Club Forki Kota Yogyakarta berjumlah 7 anak yang memiliki kriteria anak usia sekolah dasar kelas atas (10-12 tahun), pelaksanaan skala kecil didokumentasikan dalam bentuk video yang kemudian akan diobservasi ahli materi.

\section{Operasional Product Revision}

Revisi produk yang dilakukan dari hasil uji coba skala kecil, dengan menganalisis kekurangan yang ditemui dalam uji coba skala kecil, masukan yang diterima dai para pakar diltindaklanjuti dengan melakukan revisi produk

\section{Operational Field Testing}

Penelitian skala besar dilaksanakan di Club Inkanas DIY berjumlah 16 anak yang memiliki kriteria anak usia sekolah dasar kelas atas (10-12 tahun). Dalam hal ini subjek uji coba yang sudah mengikuti uji coba skala kecil tidak turut serta dalam uji coba skala besar.

\section{Final Product Revision}

Proses revisi produk dilakukan untuk mendapat masukan dari para ahli materi agar menghasilkan produk final, langkah ini merupakan penyempurnaan produk yang dikembangkan agar produk akhir lebih akurat. Pada tahap ini sudah didapatkan suatu produk berupa buku dan DVD model latihan karate kids dengan tingkat keefektivitasan tinggi dan dapat dipertanggungjawabkan.

\section{Dissemination and Implementation}

Desiminasi dan implementasi, yaitu melaporkan produk pada forum ilmiah berupa jurnal yang diterbitkan.

\section{Desain Uji Coba}

Dalam penelitian ini uji coba produk/ draf model pengembangan latihan dilakukan sebanyak dua kali, yaitu uji coba skala kecil dan uji coba skala besar. Sebelum dilaksanakan uji coba di lapangan, produk penelitian berupa draf divalidasi terlebih dahulu. Dalam tahap tersebut, selain validasi para pakar juga akan diberikan penilaian terhadap draf yang telah disusun, sehingga akan diketahui apakah model latihan yang disusun layak untuk diujicobakan di lapangan. Kemudian dalam tahap uji coba di lapangan peran dari para pakar adalah untuk mengobservasi kelayakan draf yang telah tersusun dengan kenyataan di lapangan. Akhirnya setelah uji coba skala besar maka akan menghasilkan sebuah model latihan yang benarbenar valid.

\section{Subjek Coba}

Subjek coba dalam penelitian ini adalah anak-anak yang memiliki klasifikasi anak usia sekolah dasar kelas atas (10-12 tahun) yang 
mengikuti latihan karate, yaitu uji coba produk skala kecil di Forki Kota Yogyakarta sebanyak 7 anak dan skala besar di Inkanas DIY sebanyak 16 anak. Kemudian sesuai dengan tahapan penelitian, akan dilaksanakan beberapa tahapan proses pengambilan data.

Jenis Data

Data yang dikumpulkan dari penelitian ini adalah data dari pakar/ahli. Menggunakan angket untuk menilai kualitas draf permainan sebelum uji coba di lapangan. Sedangkan uji coba di lapangan dengan skala kecil dan skala besar data dihasilkan dari hasil observasi yang diberikan kepada para pakar saat mengobservasi pelaksanaan uji coba yang telah didokumentasikan dalam bentuk video. Data kualitatif berasal dari hasil wawancara dengan pelatih pada observasi awal di club atau dojo karate, data masukan para ahli/pakar, dan ahli media. Data kuantitatif berasal dari data: (1) lembar observasi model latihan, (2) lembar observasi keefektifan model latihan, (3) angket untuk subjek coba coba skala besar dan skala kecil, dan (4) lembar observasi ahli media.

Instrumen Pengumpulan Data

\section{Wawancara}

Teknik pengumpulan data pertama yang digunakan yaitu teknik komunikasi langsung dengan menggunakan instrumen wawancara sebagai alat pengumpulan data. Definisi dari teknik komunikasi langsung adalah mekanisme pengumpulan data yang dilakukan melalui kontak atau hubungan pribadi dalam bentuk tatap muka (face to face relationship) antara pengumpulan data dengan responden. Menurut (Riduwan, 2004, p.74) wawancara adalah suatu cara pengumpulan data yang digunakan untuk memperoleh informasi langsung dari sumbernya. Wawancara ini digunakan untuk mengetahui hal-hal dari responden secara mendalam serta jumlah responden sedikit. Ada beberapa faktor yang akan mempengaruhi arus informasi dalam wawancara, yaitu: pewawancara, responden, pedoman wawancara, dan situasi wawancara. Butir-butir pertanyaan meliputi: (1) bentuk-bentuk/model latihan untuk anak-anak, (2) proses dalam latihan (respon anak terhadap latihan), (3) model latihan dengan permainan, (4) pemberian gerak dasar multilateral, (5) masalah yang dihadapi pelatih pada saat melatih anak-anak, (6) panduan dalam melatih teknik pada anak-anak.

\section{Kuesioner}

Instrumen pengumpulan data yang kedua memakai kuesioner dengan jenis skala likert. Kategori yang dimaksud dalam skala penilaian ini adalah kategori berskala empat menurut Mardapi (2008, p.121), yaitu frekuensi dihitung untuk mengetahui persentase dari kategori sangat setuju (4), setuju (3), tidak setuju (2), sangat tidak setuju (1).

\section{Observasi}

Pengumpulan data selanjutnya dengan metode observasi, menurut Mulyatiningsih (2011, p.26) "Observasi merupakan metode pengumpulan data dan pencatatan perilaku subjek penelitian yang dilakukan secara sistematik. Alat yang digunakan untuk mengobservasi dapat berupa lembar pengamatan atau check list. Observasi dilakuan secara tidak langsung melalui rekaman yang telah dibuat. Alat rekaman yang digunakan dalam penelitian ini adalah handycam, yang sudah di copy dalam bentuk video. Dengan menggunakan alat elektronik sebagai pembantu, bila terjadi keraguan atau kelupaan, rekaman dapat diputar kembali agar pencatatan data yang keliru dapat diperbaiki

\section{Instrumen Observasi Model}

Penyusunan kisi-kisi observasi model latihan karate kids dirancang sesuai dengan kajian dari teori yang berkaitan dengan variabel dalam penelitian model latihan karate kids pada anak usia sekolah dasar kelas atas (10-12 tahun) dan kemudian divalidasi oleh ahli materi

\section{Instrumen Keefektifan Model}

Penyusunan kisi-kisi observasi keefektifan model latihan karate kids dirancang sesuai dengan kajian dari teori yang berkaitan dengan variabel dalam penelitian model latihan karate kids pada anak usia sekolah dasar kelas atas (10-12 tahun) dan kemudian divalidasi oleh ahli materi. Rekonstruksi instrumen untuk mengobservasi keefektifan model memiliki arti penting, yaitu untuk mengetahui apakah model latihan yang disusun efektif atau tidak

\section{Instrumen Observasi Ahli Media}

Penyusunan instrumen observasi ahli media berkaitan dengan kualitas video dan materi yang dibuat dalam model latihan karate kids. 


\section{Angket Subjek Coba}

Pada saat uji coba skala kecil dan skala besar diambil dengan data kuantitatif untuk melihat respon anak-anak yang menjadi subjek uji coba. Diharapkan dengan mengetahui data dari anak-anak, maka kualitas model latihan akan lebih baik.

\section{Teknik Analisis Data}

Teknik analisis data yang dilakukan dalam penelitian ini yaitu analisis deskriptif kuantitatif dan analisis deskriptif kualitatif. Analisis deskriptif kuantitatif dilakukan untuk menganalisis data-data berikut: (1) data skala nilai hasil penilaian terhadap draf model latihan karate kids sebelum pelaksanaan uji coba di lapangan, (2) data hasil observasi model latihan karate kids, (3) data hasil observasi keefektifan model latihan karate kids, (4) data kuesioner oleh karate kids, dan (5) data observasi ahli media terhadap kualitas video. Sementara analisis deskriptif kualitatif dilakukan terhadap: (1) data hasil wawancara dengan pelatih saat studi pendahuluan, (2) data kekurangan dan masukan terhadap model latihan karate kids sebelum uji coba maupun setelah uji coba di lapangan.

Draf awal latihan karate kids dianggap layak untuk diujicobakan dalam skala kecil apabila para ahli materi telah memberi validasi terhadap instrumen dan layak untuk diujicobakan. Dalam hal ini terdapat empat jenis nilai, yaitu hasil penilaian sangat setuju mendapat nilai empat (4) setuju mendapat nilai tiga (3) tidak setuju mendapat nilai dua (2) dan sangat tidak setuju mendapat nilai satu (1). Jika ahli materi berpendapat bahwa item klasifikasi tidak sesuai, maka dilakukan pengkajian ulang terhadap model latihan karate kids yang dapat ditindaklanjuti dengan proses revisi. Terlebih dahulu ditentukan kategori skor penilaian data hasil observasi model latihan, data observasi keefektifan model latihan, dan data observasi ahli media terhadap kualitas video, sedangkan data dari hasil kuesioner yang diberikan anak-anak akan dianalisis untuk mendapatkan persentase. Berikut adalah kategori skor penilaian menurut Azwar (2004, p.109):
Tabel 1.Kategori Skor (Azwar, 2004, p.109)

\begin{tabular}{cc}
\hline Formula & Kategori \\
\hline $\mathrm{X}<(\mu-1,0 \sigma)$ & Rendah \\
$(\mu-1,0 \sigma) \leq X<(\mu+1,0 \sigma)$ & Sedang \\
$(\mu+1,0 \sigma) \leq X$ & Tinggi \\
\hline
\end{tabular}

Penghitungan Normatif Kategorisasi

Keterangan:

$\mathrm{X}=$ jumlah skor subyek.

$\mu=$ mean ideal $=1 / 2[(X .4)+(X .1)]$

$\sigma=$ standar devisiasi ideal $=1 / 6[(\mathrm{X} .4)-(\mathrm{X} .1)]$

\section{Hasil Penelitian dan Pembahasan}

Penelitian ini terdapat empat model yang dikembangkan antara lain: (1) model latihan maegeri, (2) model latihan gyaku tsuki, (3) model latihan mawashigeri, dan (4) model latihan oi tsuki. Berikut hasil penilai ahli materi dan pelatih dalam model latihan karate kids pada anak usia sekolah dasar kelas atas (10-12 tahun

\section{Model Latihan Maegeri}

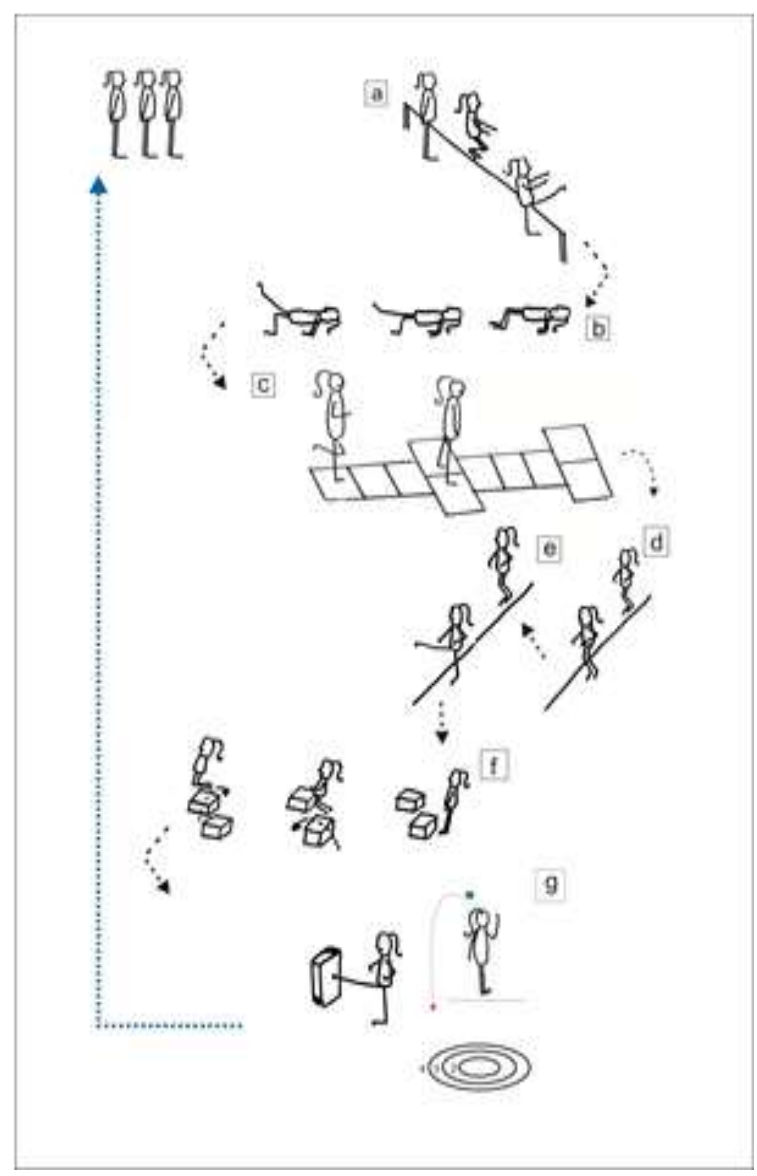

Latihan ini menggunakan model circuit game yaitu sebagai berikut: anak-anak berbaris untuk menentukan giliran dalam bermain, melakukan play jumping and kicking the rope 
(bermain tali dan menendang), crab walk (berjalan menyerupai kepiting), engkling, crossing line (meloncat melintasi garis), crossing line and kick (meloncat melintasi garis dan menendang), jump side and front (meloncat ke samping dan ke depan), lempar kereweng kemudian melakukan tendangan maegeri dengan jumlah tendangan sesuai kereweng/gacuk mengenai sasaran angka yang dituju.

Model Latihan Gyaku Tsuki

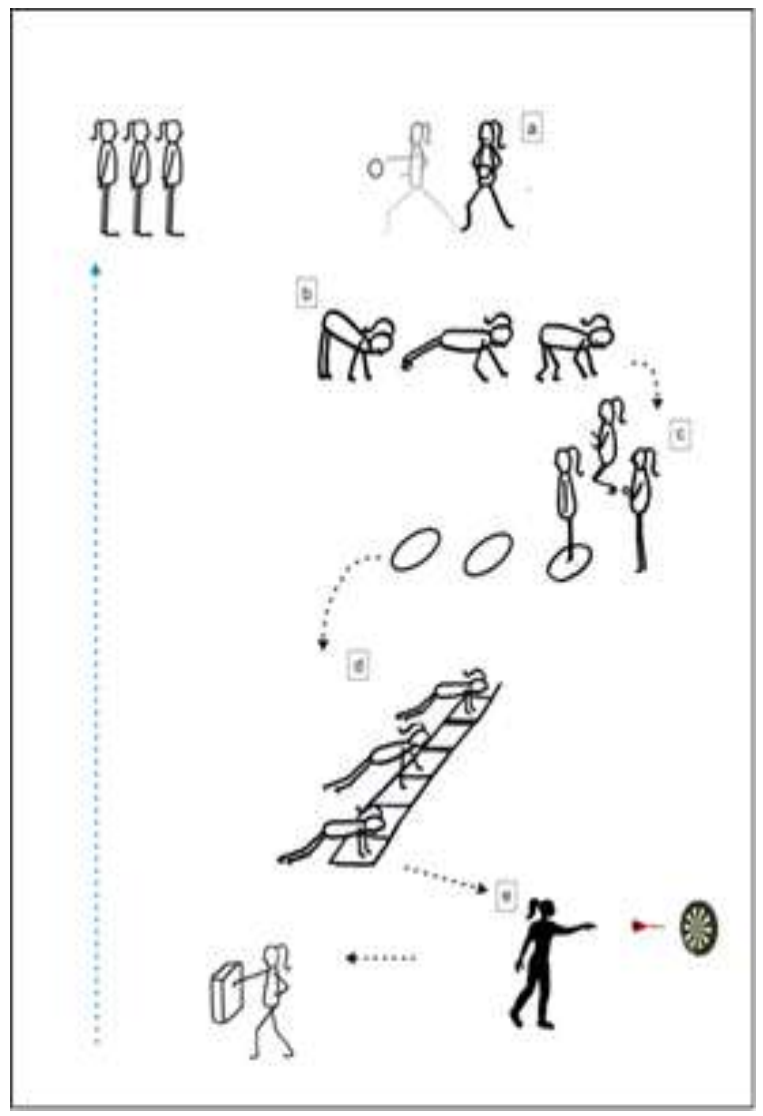

Latihan menggunakan model circuit game yaitu sebagai berikut: anak-anak berbaris untuk menentukan giliran dalam bermain, melakukan throwing the ball (melontarkan/melempar bola ke depan seperti teknik gyaku tsuki), walking snake (merangkak meyerupai ular), jumping with holahop, hand-walk sideways through ladder (berjalan dengan tumpuan tangan menyamping memakai ladder), bermain dart board kemudian melakukan pukulan gyaku tsuki jumlah pukulan sesuai sasaran panah yang dituju pada papan angka dart board.
Model Latihan Mawashigeri

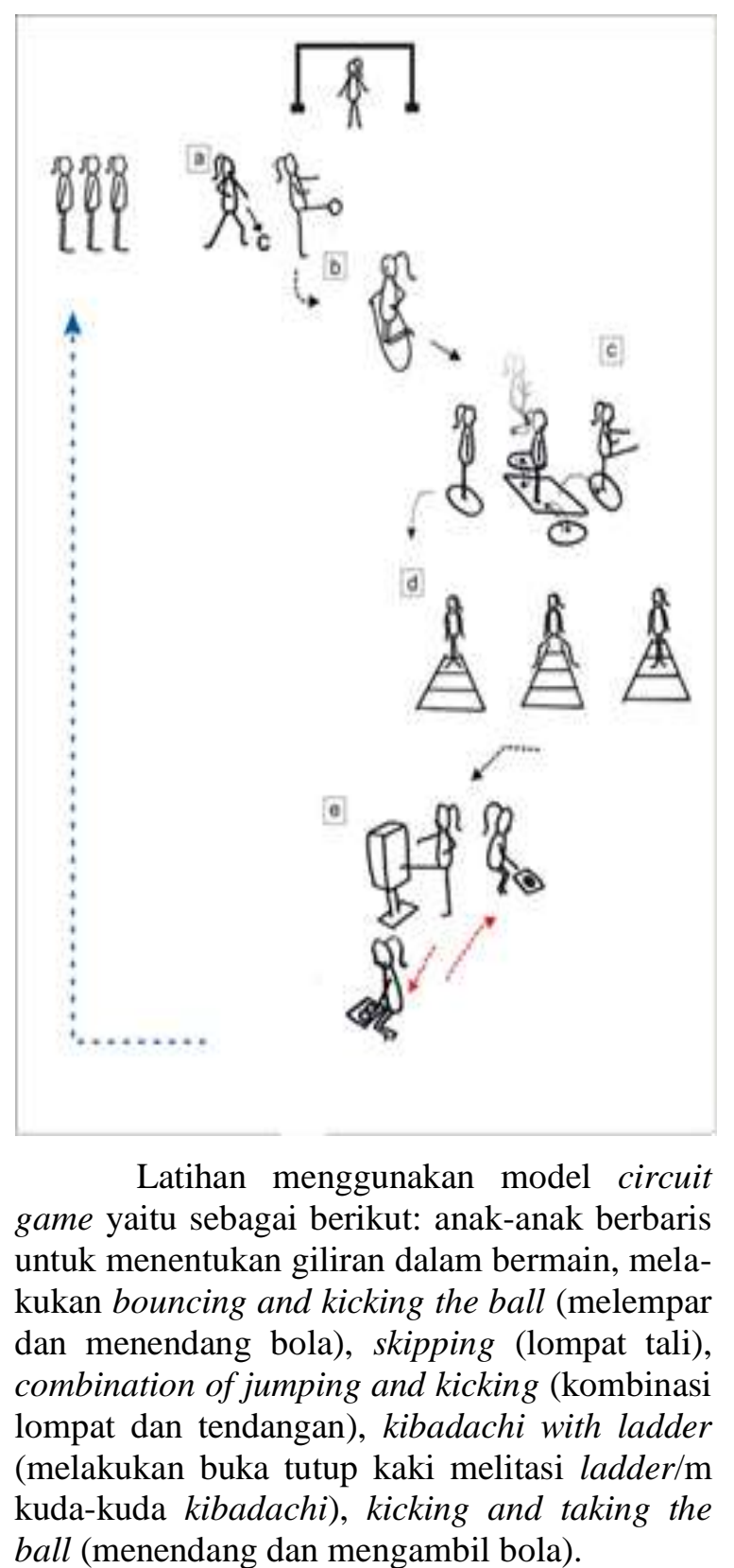


Model Latihan Oi Tsuki

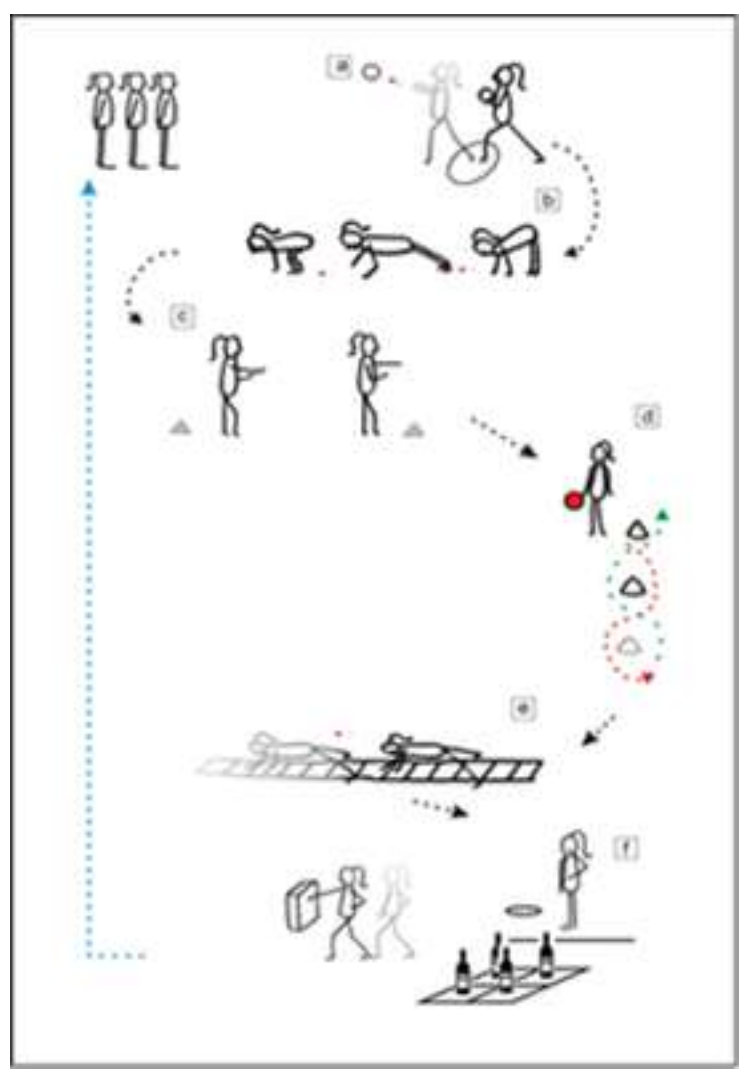

Latihan menggunakan model circuit game yaitu sebagai berikut: anak-anak berbaris untuk menentukan giliran dalam bermain, melakukan throwing the ball (melempar bola) ke ring/lubang, snake jump (berjalan melompat menyerupai ular), running and punch (berlari dan memukul), zig-zag and drible (zig-zag dengan memantulkan bola), hand-walk to front through ladder (berjalan dengan tumpuan tangan melewati lintasan ladder), melempar gelang dan memukul oi tsuki.

Skala Kecil

\section{Observasi Model Latihan Maegeri}

Penilaian ahli materi dan pelatih terhadap latihan karate kids untuk melatih maegeri: $(0 \%)$ yang kategori rendah, $(0 \%)$ yang kategori sedang, dan 4 responden $(100,00 \%)$ kategori tinggi. Total nilai pakar 1 sebesar 50 terletak pada interval $42 \leq \mathrm{X}$, total nilai pakar 2 sebesar 52 terletak pada interval $42 \leq \mathrm{X}$, total nilai pelatih 1 sebesar 47 terletak pada interval $42 \leq$ $X$, total nilai pelatih 2 sebesar 52 terletak pada interval $42 \leq \mathrm{X}$, maka pada penelitian skala kecil penilaian ahli materi dan pelatih terhadap observasi model latihan maegeri dalam kategori tinggi/baik.
Tabel 2.Distribusi Frekuensi (Azwar, 2004, p.110)

\begin{tabular}{cccc}
\hline Interval & Kategori & Frekuensi & $\%$ \\
\hline $\mathrm{X}<28$ & Rendah & 0 & $0,00 \%$ \\
$28 \leq \mathrm{X}<42$ & Sedang & 0 & $0,00 \%$ \\
$42 \leq \mathrm{X}$ & Tinggi & 4 & $100,00 \%$ \\
Jumlah & & 4 & $100,00 \%$ \\
\hline
\end{tabular}

Keefektifan Model Latihan Maegeri

Penilaian ahli materi dan pelatih terhadap latihan karate kids untuk melatih maegeri: $(0 \%)$ yang kategori rendah, $(0 \%)$ yang kategori sedang, dan 4 responden $(100,00 \%)$ kategori tinggi. Total nilai pakar 1 sebesar 35 terletak pada interval $30 \leq \mathrm{X}$, total nilai pakar 2 sebesar 34 terletak pada interval $30 \leq \mathrm{X}$, total nilai pelatih 1 sebesar 34 terletak pada interval $30 \leq$ $\mathrm{X}$, total nilai pelatih 2 sebesar 37 terletak pada interval $30 \leq \mathrm{X}$, maka pada penelitian skala kecil penilaian ahli materi dan pelatih terhadap observasi keefektifan model latihan maegeri dalam kategori tinggi/efektif.

Tabel 3. Distribusi frekuensi (Azwar, 2004,

$$
\text { p.110) }
$$

\begin{tabular}{cccc}
\hline Interval & Kategori & Frekuensi & \% \\
\hline $\mathrm{X}<20$ & Rendah & 0 & $0,00 \%$ \\
$20 \leq \mathrm{X}<30$ & Sedang & 0 & $0,00 \%$ \\
$30 \leq \mathrm{X}$ & Tinggi & 4 & $100,00 \%$ \\
Jumlah & & 4 & $100,00 \%$ \\
\hline
\end{tabular}

Observasi Model Latihan Gyaku Tsuki

Penilaian ahli materi dan pelatih terhadap latihan karate kids untuk melatih gyaku tsuki: $(0 \%)$ yang kategori rendah, $(0 \%)$ yang kategori sedang, dan 4 responden $(100,00 \%)$ kategori tinggi. Total nilai pakar 1 sebesar 52 terletak pada interval $42 \leq \mathrm{X}$, total nilai pakar 2 sebesar 54 terletak pada interval $42 \leq X$, total nilai pelatih 1 sebesar 48 terletak pada interval $42 \leq \mathrm{X}$, total nilai pelatih 2 sebesar 52 terletak pada interval $42 \leq \mathrm{X}$, maka pada penelitian skala kecil penilaian ahli materi dan pelatih terhadap observasi model latihan gyaku tsuki dalam kategori tinggi/baik.

Tabel 4.Distribusi frekuensi (Azwar, 2004, p.110)

\begin{tabular}{cccc}
\hline Interval & Kategori & Frekuensi & \% \\
\hline $\mathrm{X}<28$ & Rendah & 0 & $0,00 \%$ \\
$28 \leq \mathrm{X}<42$ & Sedang & 0 & $0,00 \%$ \\
$42 \leq \mathrm{X}$ & Tinggi & 4 & $100,00 \%$ \\
Jumlah & & 4 & $100,00 \%$ \\
\hline
\end{tabular}




\section{Keefektifan Model Latihan Gyaku Tsuki}

Penilaian ahli materi dan pelatih terhadap latihan karate kids untuk melatih gyaku tsuki: (0\%) yang kategori rendah, $(0 \%)$ yang kategori sedang, dan 4 responden $(100,00 \%)$ kategori tinggi. Total nilai pakar 1 sebesar 33 terletak pada interval $30 \leq \mathrm{X}$, total nilai pakar 2 sebesar 34 terletak pada interval $30 \leq \mathrm{X}$, total nilai pelatih 1 sebesar 35 terletak pada interval $30 \leq X$, total nilai pelatih 2 sebesar 36 terletak pada interval $30 \leq \mathrm{X}$, maka pada penelitian skala kecil penilaian ahli materi dan pelatih terhadap observasi keefektifan model latihan gyaku tsuki dalam kategori tinggi/efektif.

Tabel 5.Distribusi frekuensi (Azwar, 2004, p.110)

\begin{tabular}{cccc}
\hline Interval & Kategori & Frekuensi & \% \\
\hline $\mathrm{X}<20$ & Rendah & 0 & $0,00 \%$ \\
$20 \leq \mathrm{X}<30$ & Sedang & 0 & $0,00 \%$ \\
$30 \leq \mathrm{X}$ & Tinggi & 4 & $100,00 \%$ \\
Jumlah & & 4 & $100,00 \%$ \\
\hline
\end{tabular}

Observasi Model Latihan Mawashigeri

Penilaian ahli materi dan pelatih terhadap latihan karate kids untuk melatih mawashigeri: $(0 \%)$ yang kategori rendah, $(0 \%)$ yang kategori sedang, dan 4 responden $(100,00 \%)$ kategori tinggi. Total nilai pakar 1 sebesar 50 terletak pada interval $42 \leq \mathrm{X}$, total nilai pakar 2 sebesar 53 terletak pada interval $42 \leq \mathrm{X}$, total nilai pelatih 1 sebesar 45 terletak pada interval $42 \leq X$, total nilai pelatih 2 sebesar 51 terletak pada interval $42 \leq \mathrm{X}$, maka pada penelitian skala kecil penilaian ahli materi dan pelatih terhadap observasi model latihan mawashigeri dalam kategori tinggi/baik.

Tabel 6. Distribusi frekuensi (Azwar, 2004, p.110)

\begin{tabular}{cccc}
\hline Interval & Kategori & Frekuensi & $\%$ \\
\hline $\mathrm{X}<28$ & Rendah & 0 & $0,00 \%$ \\
$28 \leq \mathrm{X}<42$ & Sedang & 0 & $0,00 \%$ \\
$42 \leq \mathrm{X}$ & Tinggi & 4 & $100,00 \%$ \\
Jumlah & & 4 & $100,00 \%$ \\
\hline
\end{tabular}

Keefektifan Model Latihan Mawasigeri

Penilaian ahli materi dan pelatih terhadap latihan karate kids untuk melatih mawashigeri: $(0 \%)$ yang kategori rendah, $(0 \%)$ yang kategori sedang, dan 4 responden $(100,00 \%)$ kategori tinggi. Total nilai pakar 1 sebesar 35 terletak pada interval $30 \leq X$, total nilai pakar 2 sebesar
34 terletak pada interval $30 \leq \mathrm{X}$, total nilai pelatih 1 sebesar 35 terletak pada interval $30 \leq$ $\mathrm{X}$, total nilai pelatih 2 sebesar 37 terletak pada interval $30 \leq \mathrm{X}$, maka pada penelitian skala kecil penilaian ahli materi dan pelatih terhadap observasi keefektifan model latihan mawashigeri dalam kategori tinggi/efektif.

Tabel 7. Distribusi frekuensi (Azwar, 2004,

$$
\text { p.110) }
$$

\begin{tabular}{cccc}
\hline Interval & Kategori & Frekuensi & $\%$ \\
\hline $\mathrm{X}<20$ & Rendah & 0 & $0,00 \%$ \\
$20 \leq \mathrm{X}<30$ & Sedang & 0 & $0,00 \%$ \\
$30 \leq \mathrm{X}$ & Tinggi & 4 & $100,00 \%$ \\
Jumlah & & 4 & $100,00 \%$ \\
\hline
\end{tabular}

Observasi Model Latihan Oi Tsuki

Penilaian ahli materi dan pelatih terhadap latihan karate kids untuk melatih oi tsuki: (0\%) yang kategori rendah, $(0 \%)$ yang kategori sedang, dan 4 responden $(100,00 \%)$ kategori tinggi. Total nilai pakar 1 sebesar 49 terletak pada interval $42 \leq X$, total nilai pakar 2 sebesar 50 terletak pada interval $42 \leq \mathrm{X}$, total nilai pelatih 1 sebesar 45 terletak pada interval $42 \leq$ $\mathrm{X}$, total nilai pelatih 2 sebesar 53 terletak pada interval $42 \leq \mathrm{X}$, maka pada penelitian skala kecil penilaian ahli materi dan pelatih terhadap observasi model latihan oi tsuki dalam kategori tinggi/baik.

Tabel 8. Distribusi frekuensi (Azwar, 2004, p.110)

\begin{tabular}{cccc}
\hline Interval & Kategori & Frekuensi & \% \\
\hline $\mathrm{X}<28$ & Rendah & 0 & $0,00 \%$ \\
$28 \leq \mathrm{X}<42$ & Sedang & 0 & $0,00 \%$ \\
$42 \leq \mathrm{X}$ & Tinggi & 4 & $100,00 \%$ \\
Jumlah & & 4 & $100,00 \%$ \\
\hline
\end{tabular}

Keefektifan Model Latihan Oi Tsuki

Penilaian ahli materi dan pelatih terhadap latihan karate kids untuk melatih oi tsuki: $(0 \%)$ yang kategori rendah, $(0 \%)$ yang kategori sedang, dan 4 responden $(100,00 \%)$ kategori tinggi. Total nilai pakar 1 sebesar 32 terletak pada interval $30 \leq \mathrm{X}$, total nilai pakar 2 sebesar 34 terletak pada interval $30 \leq \mathrm{X}$, total nilai pelatih 1 sebesar 31 terletak pada interval $30 \leq$ $\mathrm{X}$, total nilai pelatih 2 sebesar 37 terletak pada interval $30 \leq X$, maka pada penelitian skala kecil penilaian ahli materi dan pelatih terhadap observasi keefektifan model latihan oi tsuki dalam kategori tinggi/efektif. 
Tabel 9. Distribusi frekuensi (Azwar, 2004, p.110)

\begin{tabular}{cccc}
\hline Interval & Kategori & Frekuensi & \% \\
\hline $\mathrm{X}<20$ & Rendah & 0 & $0,00 \%$ \\
$20 \leq \mathrm{X}<30$ & Sedang & 0 & $0,00 \%$ \\
$30 \leq \mathrm{X}$ & Tinggi & 4 & $100,00 \%$ \\
Jumlah & & 4 & $100,00 \%$ \\
\hline
\end{tabular}

\section{Angket Subjek Coba}

Respon dari peserta yang menjadi sampel pada uji coba skala kecil, secara umum memberikan respon yang positif terhadap model latihan karate kids pada anak usia sekolah dasar kelas atas (10-12 tahun).

\section{Penilaian Ahli Media}

Penilaian ahli media terhadap kualitas video latihan karate kids pada anak usia sekolah dasar kelas atas (10-12 tahun), total nilai model latihan maegeri sebesar 28 terletak pada interval $24 \leq \mathrm{X}$, total nilai model latihan gyaku tsuki sebesar 26 terletak pada interval $24 \leq \mathrm{X}$, total nilai model latihan mawashigeri sebesar 27 terletak pada interval $24 \leq \mathrm{X}$, total nilai model latihan oi tsuki sebesar 26 terletak pada interval $24 \leq \mathrm{X}$, maka pada penelitian skala kecil penilaian ahli media terhadap kualitas video dalam kategori tinggi/baik

Tabel 10. Distribusi frekuensi (Azwar, 2004, p.110)

\begin{tabular}{ccc}
\hline Formula & Batasan & Kategori \\
\hline $\mathrm{X}<(\mu-1,0 \sigma)$ & $\mathrm{X}<16$ & Rendah \\
$(\mu-1,0 \sigma) \leq \mathrm{X}<(\mu+1,0 \sigma)$ & $16 \leq \mathrm{X}<24$ & Sedang \\
$(\mu+1,0 \sigma) \leq \mathrm{X}$ & $24 \leq \mathrm{X}$ & Tinggi \\
\hline
\end{tabular}

Skala Besar

\section{Observasi Model Latihan Maegeri}

Penilaian ahli materi dan pelatih terhadap latihan karate kids untuk melatih maegeri: $(0 \%)$ yang kategori rendah, $(0 \%)$ yang kategori sedang, dan 4 responden $(100,00 \%)$ kategori tinggi. Total nilai pakar 1 sebesar 56 terletak pada interval $42 \leq \mathrm{X}$, total nilai pakar 2 sebesar 55 terletak pada interval $42 \leq \mathrm{X}$, total nilai pelatih 1 sebesar 56 terletak pada interval $42 \leq$ $\mathrm{X}$, total nilai pelatih 2 sebesar 56 terletak pada interval $42 \leq \mathrm{X}$, maka pada penelitian skala besar penilaian ahli materi dan pelatih terhadap observasi model latihan maegeri dalam kategori tinggi/baik.
Tabel 11. Distribusi frekuensi (Azwar, 2004, p.110)

\begin{tabular}{cccc}
\hline Interval & Kategori & Frekuensi & \% \\
\hline $\mathrm{X}<28$ & Rendah & 0 & $0,00 \%$ \\
$28 \leq \mathrm{X}<42$ & Sedang & 0 & $0,00 \%$ \\
$42 \leq \mathrm{X}$ & Tinggi & 4 & $100,00 \%$ \\
Jumlah & & 4 & $100,00 \%$ \\
\hline
\end{tabular}

Keefektifan Model Latihan Maegeri

Penilaian ahli materi dan pelatih terhadap latihan karate kids untuk melatih maegeri: $(0 \%)$ yang kategori rendah, $(0 \%)$ yang kategori sedang, dan 4 responden $(100,00 \%)$ kategori tinggi. Total nilai pakar 1 sebesar 39 terletak pada interval $30 \leq \mathrm{X}$, total nilai pakar 2 sebesar 40 terletak pada interval $30 \leq \mathrm{X}$, total nilai pelatih 1 sebesar 40 terletak pada interval $30 \leq$ $X$, total nilai pelatih 2 sebesar 40 terletak pada interval $30 \leq \mathrm{X}$, maka pada penelitian skala besar penilaian ahli materi dan pelatih terhadap observasi keefektifan model latihan maegeri dalam kategori tinggi/efektif.

Tabel 12. Distribusi frekuensi (Azwar, 2004,

$$
\text { p.110) }
$$

\begin{tabular}{cccc}
\hline Interval & Kategori & Frekuensi & $\%$ \\
\hline $\mathrm{X}<20$ & Rendah & 0 & $0,00 \%$ \\
$20 \leq \mathrm{X}<30$ & Sedang & 0 & $0,00 \%$ \\
$30 \leq \mathrm{X}$ & Tinggi & 4 & $100,00 \%$ \\
Jumlah & & 4 & $100,00 \%$ \\
\hline
\end{tabular}

Observasi Model Latihan Gyaku Tsuki

Penilaian ahli materi dan pelatih terhadap latihan karate kids untuk melatih gyaku tsuki: $(0 \%)$ yang kategori rendah, $(0 \%)$ yang kategori sedang, dan 4 responden $(100,00 \%)$ kategori tinggi. Total nilai pakar 1 sebesar 55 terletak pada interval $42 \leq \mathrm{X}$, total nilai pakar 2 sebesar 55 terletak pada interval $42 \leq X$, total nilai pelatih 1 sebesar 56 terletak pada interval $42 \leq \mathrm{X}$, total nilai pelatih 2 sebesar 56 terletak pada interval $42 \leq \mathrm{X}$, maka pada penelitian skala besar penilaian ahli materi dan pelatih terhadap observasi model latihan gyaku tsuki dalam kategori tinggi/baik.

Tabel 13. Distribusi frekuensi (Azwar, 2004, p.110)

\begin{tabular}{cccc}
\hline Interval & Kategori & Frekuensi & \% \\
\hline $\mathrm{X}<28$ & Rendah & 0 & $0,00 \%$ \\
$28 \leq \mathrm{X}<42$ & Sedang & 0 & $0,00 \%$ \\
$42 \leq \mathrm{X}$ & Tinggi & 4 & $100,00 \%$ \\
Jumlah & & 4 & $100,00 \%$ \\
\hline
\end{tabular}




\section{Keefektifan Model Latihan Gyaku Tsuki}

Penilaian ahli materi dan pelatih terhadap latihan karate kids untuk melatih gyaku tsuki: (0\%) yang kategori rendah, $(0 \%)$ yang kategori sedang, dan 4 responden $(100,00 \%)$ kategori tinggi. Total nilai pakar 1 sebesar 40 terletak pada interval $30 \leq \mathrm{X}$, total nilai pakar 2 sebesar 39 terletak pada interval $30 \leq \mathrm{X}$, total nilai pelatih 1 sebesar 40 terletak pada interval $30 \leq X$, total nilai pelatih 2 sebesar 40 terletak pada interval $30 \leq \mathrm{X}$, maka pada penelitian skala besar penilaian ahli materi dan pelatih terhadap observasi keefektifan model latihan gyaku tsuki dalam kategori tinggi/efektif.

Tabel 14.Distribusi frekuensi (Azwar, 2004, p.110)

\begin{tabular}{cccc}
\hline Interval & Kategori & Frekuensi & \% \\
\hline $\mathrm{X}<20$ & Rendah & 0 & $0,00 \%$ \\
$20 \leq \mathrm{X}<30$ & Sedang & 0 & $0,00 \%$ \\
$30 \leq \mathrm{X}$ & Tinggi & 4 & $100,00 \%$ \\
Jumlah & & 4 & $100,00 \%$ \\
\hline
\end{tabular}

Observasi Model Latihan Mawashigeri

Penilaian ahli materi dan pelatih terhadap latihan karate kids untuk melatih mawashigeri: $(0 \%)$ yang kategori rendah, $(0 \%)$ yang kategori sedang, dan 4 responden $(100,00 \%)$ kategori tinggi. Total nilai pakar 1 sebesar 56 terletak pada interval $42 \leq \mathrm{X}$, total nilai pakar 2 sebesar 54 terletak pada interval $42 \leq \mathrm{X}$, total nilai pelatih 1 sebesar 56 terletak pada interval $42 \leq X$, total nilai pelatih 2 sebesar 56 terletak pada interval $42 \leq \mathrm{X}$, maka pada penelitian skala besar penilaian ahli materi dan pelatih terhadap observasi model latihan mawashigeri dalam kategori tinggi/baik.

Tabel 15. Distribusi frekuensi (Azwar, 2004, p.110)

\begin{tabular}{cccc}
\hline Interval & Kategori & Frekuensi & $\%$ \\
\hline $\mathrm{X}<28$ & Rendah & 0 & $0,00 \%$ \\
$28 \leq \mathrm{X}<42$ & Sedang & 0 & $0,00 \%$ \\
$42 \leq \mathrm{X}$ & Tinggi & 4 & $100,00 \%$ \\
Jumlah & & 4 & $100,00 \%$ \\
\hline
\end{tabular}

Keefektifan Model Latihan Mawashigeri

Penilaian ahli materi dan pelatih terhadap latihan karate kids untuk melatih mawashigeri: $(0 \%)$ yang kategori rendah, $(0 \%)$ yang kategori sedang, dan 4 responden $(100,00 \%)$ kategori tinggi. Total nilai pakar 1 sebesar 40 terletak pada interval $30 \leq \mathrm{X}$, total nilai pakar 2 sebesar 40 terletak pada interval $30 \leq \mathrm{X}$, total nilai pelatih 1 sebesar 40 terletak pada interval $30 \leq \mathrm{X}$, total nilai pelatih 2 sebesar 40 terletak pada interval $30 \leq \mathrm{X}$, maka pada penelitian skala besar penilaian ahli materi dan pelatih terhadap observasi keefektifan model latihan mawashigeri dalam kategori tinggi/efektif.

Tabel 16. Distribusi frekuensi (Azwar, 2004,

$$
\text { p.110) }
$$

\begin{tabular}{cccc}
\hline Interval & Kategori & Frekuensi & \% \\
\hline $\mathrm{X}<20$ & Rendah & 0 & $0,00 \%$ \\
$20 \leq \mathrm{X}<30$ & Sedang & 0 & $0,00 \%$ \\
$30 \leq \mathrm{X}$ & Tinggi & 4 & $100,00 \%$ \\
Jumlah & & 4 & $100,00 \%$ \\
\hline
\end{tabular}

\section{Observasi Model Latihan Oi Tsuki}

Penilaian ahli materi dan pelatih terhadap latihan karate kids untuk melatih oi tsuki: (0\%) yang kategori rendah, $(0 \%)$ yang kategori sedang, dan 4 responden $(100,00 \%)$ kategori tinggi. Total nilai pakar 1 sebesar 55 terletak pada interval $42 \leq X$, total nilai pakar 2 sebesar 56 terletak pada interval $42 \leq \mathrm{X}$, total nilai pelatih 1 sebesar 56 terletak pada interval $42 \leq$ $\mathrm{X}$, total nilai pelatih 2 sebesar 56 terletak pada interval $42 \leq \mathrm{X}$, maka pada penelitian skala besar penilaian ahli materi dan pelatih terhadap observasi model latihan oi tsuki dalam kategori tinggi/baik.

Tabel 17. Distribusi frekuensi (Azwar, 2004, p.110)

\begin{tabular}{cccc}
\hline Interval & Kategori & Frekuensi & \% \\
\hline $\mathrm{X}<28$ & Rendah & 0 & $0,00 \%$ \\
$28 \leq \mathrm{X}<42$ & Sedang & 0 & $0,00 \%$ \\
$42 \leq \mathrm{X}$ & Tinggi & 4 & $100,00 \%$ \\
Jumlah & & 4 & $100,00 \%$ \\
\hline
\end{tabular}

Keefektifan Model Latihan Oi Tsuki

penilaian ahli materi dan pelatih terhadap latihan karate kids untuk melatih oi tsuki: $(0 \%)$ yang kategori rendah, $(0 \%)$ yang kategori sedang, dan 4 responden $(100,00 \%)$ kategori tinggi. Total nilai pakar 1 sebesar 40 terletak pada interval $30 \leq \mathrm{X}$, total nilai pakar 2 sebesar 40 terletak pada interval $30 \leq \mathrm{X}$, total nilai pelatih 1 sebesar 40 terletak pada interval $30 \leq$ $\mathrm{X}$, total nilai pelatih 2 sebesar 40 terletak pada interval $30 \leq \mathrm{X}$, maka pada penelitian skala besar penilaian ahli materi dan pelatih terhadap observasi keefektifan model latihan oi tsuki dalam kategori tinggi/efektif. 
Tabel 18. Distribusi frekuensi (Azwar, 2004, p.110)

\begin{tabular}{cccc}
\hline Interval & Kategori & Frekuensi & \% \\
\hline $\mathrm{X}<20$ & Rendah & 0 & $0,00 \%$ \\
$20 \leq \mathrm{X}<30$ & Sedang & 0 & $0,00 \%$ \\
$30 \leq \mathrm{X}$ & Tinggi & 4 & $100,00 \%$ \\
Jumlah & & 4 & $100,00 \%$ \\
\hline
\end{tabular}

Angket Subjek Coba

Berdasarkan tabel rekapitulasi kuesioner untuk karate kids di atas menunjukan bahwa respon dari peserta yang menjadi sampel pada uji coba skala besar, secara umum memberikan respon yang positif terhadap model latihan karate kids pada anak usia sekolah dasar kelas atas (10-12 tahun).

\section{Penilaian Ahli Media}

Penilaian ahli media terhadap kualitas video latihan karate kids pada anak usia sekolah dasar kelas atas (10-12 tahun), total nilai model latihan maegeri sebesar 31 terletak pada interval $24 \leq \mathrm{X}$, total nilai model latihan gyaku tsuki sebesar 31 terletak pada interval $24 \leq \mathrm{X}$, total nilai model latihan mawashigeri sebesar 30 terletak pada interval $24 \leq \mathrm{X}$, total nilai model latihan oi tsuki sebesar 32 terletak pada interval $24 \leq X$, maka pada penelitian skala besar penilaian ahli media terhadap kualitas video dalam kategori tinggi/baik.

Tabel 19.Distribusi frekuensi (Azwar, 2004, p.110)

\begin{tabular}{ccc}
\hline Formula & Batasan & Kategori \\
\hline $\mathrm{X}<(\mu-1,0 \sigma)$ & $\mathrm{X}<16$ & Rendah \\
$(\mu-1,0 \sigma) \leq \mathrm{X}<(\mu+1,0 \sigma)$ & $16 \leq \mathrm{X}<24$ & Sedang \\
$(\mu+1,0 \sigma) \leq \mathrm{X}$ & $24 \leq \mathrm{X}$ & Tinggi \\
\hline
\end{tabular}

\section{Simpulan dan Saran}

Simpulan

Menghasilkan model latihan karate kids pada anak usia sekolah dasar kelas atas (10-12 tahun) yang baik dan efektif, yaitu: (a) model latihan maegeri, model latihan gyaku tsuki, model latihan mawashigeri, dan (4) model latihan oi tsuki.

Subjek coba dalam penelitian ini (karate kids): memberikan respon yang positif terhadap model model latihan karate kids pada anak usia sekolah dasar kelas atas (10-12 tahun): (a) Anak merasa senang dengan model latihan karate kids dan tetarik dengan peralatan yang digunakan, (b) Anak ingin kembali mengulang latihan dengan model latihan karate kids, (c) Dengan model latihan karate kids, anak merasa aktif bergerak

Dari analisi tersebut dapat disimpulkan bahwa produk dari penelitian pengembangan ini berupa model latihan karate kids pada anak usia sekolah dasar kelas atas (10-12), dengan produk yang dihasilkan berupa buku dan DVD, yang terdiri dari empat model latihan yaitu: (1) model latihan maegeri, (2) model latihan gyaku tsuki, (3) model latihan mawashigeri, dan (4) model latihan oi tsuki yang valid, efektif dan layak untuk digunakan.

Saran

\section{Saran Pemanfaatan}

Model latihan karate kids pada anak usia sekolah dasar kelas atas (10-12 tahun) sebagai produk yang dihasilkan sebagai bahan referensi bagi pelatih dalam menyusun program latihan yang menyenangkan dan aktif aktif bergerak.

\section{Diseminasi}

Diseminasi hasil penelitian pengembangan ini dapat dilakukan melalui seminarseminar, pembuatan artikel, sosialisasi model latihan karate kids melalui forum pelatih (training of trainer).

\section{Pengembangan Produk Lebih Lanjut}

Penelitian ini dapat sebagai dasar penelitian eksperimen mengenai variabel-variabel yang akan diteliti, dapat juga melakukan penelitian pengembangan serupa dengan sasaran subjek pada anak usia sekolah dasar kelas bawah ataupun usia taman kanak-kanak, subjek lebih besar, luas, dan dengan model yang lebih banyak.

\section{Daftar Pustaka}

Azwar, Saifuddin. (2004). Penyusunan skala psikologi. Yogyakarta: Pustaka Pelajar Offset.

Borg, Walter R. \& Gall., M.D (2003). Educational research. (an introduction), $7^{\text {th }}$ edition. New York \& London: Longman.

Goldstein, Jeffrey. (2012). Play in children's development, health and well-being. Netherlands: Utretcht University.

Lumintuarso, Ria. (2013). Pembinaan multilateral bagi atlet pemula. Yogyakarta: UNY Press. 
Mardapi, Djemari. (2008). Teknik penyusunan instrumen tes dan nontes. Yogyakarta: Mitra Cendikia Press.

Mini, Rose. (2003). Perilaku anak. Jakarta: Erlangga.

Mulyatiningsih, Endang. (2011). Riset terapan bidang pendidikan \& teknik. Yogyakarta: UNY Press.

Purwanto, Sugeng. (2009). Pembinaan prestasi olahraga karate. Yogyakarta: Jurnal iptek olahraga, Vol. 11, No. 2, Mei 2009, pp.171-181, UNY.

Rusman. (2013). Model-model pembelajaran: Mengembangkan profesionalisme guru $E d$. 2. Jakarta: Rajawali Pers.

Sukadiyanto. (2002). Teori dan metodologi melatih fisik petenis. Yogyakarta: UNY. 